\title{
Future tasks of electrochemical research: the fascinating world of solids
}

\author{
Werner J.F. Weppner ${ }^{1}$
}

Received: 20 July 2020 / Revised: 20 July 2020 / Accepted: 21 July 2020 / Published online: 18 August 2020

(C) The Author(s) 2020

Solids show a wide variety of fascinating properties. Not only the structure itself is commonly favorable; the kinetic properties in particular are far more diverse than in liquids and gases. The diffusion of components can be as high as in gases and so low that no change takes place in millions of years. The number and variation of solids are practically unlimited. This results in the discovery of solids with surprising and fascinating new properties. Their characterization is commonly not easy and requires very careful basic knowledge. The preparation and handling are often another challenge. Beyond all of that, the discovery of exciting functional properties is particularly rewarding.

Of special interest are the conductivities of ions and electrons and their interaction in combination with thermodynamic and structural data. Fast ion transport in some solids has led to galvanic cells in solid state. The development of such cells is now playing an important role for practical applications. The present focus is particularly in areas of protecting the environment and conserving natural resources. Prominent examples are materials for high energy and power density batteries, fuel cells, electrolysis cells, electrochromic devices, chemical sensors, thermoelectric converters, and photogalvanic solar cells.

None of the applications consists of only one material. Combinations of materials with mostly quite different properties are always required. The voltages occur generally only at the interfaces. The combined solids must have suitable and generally quite different kinetic and thermodynamic properties. These requirements are outstanding challenges. In addition, the properties of the solids change as the ions move through the galvanic cells. The name Ionics was generated for such applications and basic research. This expression is reminiscent of Electronics, but the challenges are an order of magnitude larger due to the involvement of both ionic and electronic charge carriers. Students and researchers should have good knowledge of both chemistry and physics.

The foundations for the development of electrochemistry with solid substances have been laid in recent years. The first suitable electrolyte and electrode materials for allsolid-state batteries, fuel cells, sensors, and electrochromic devices have been developed and are being tested as prototypes. They are the basis for continuous improvements. In this way, materials research in the field of ion conduction in solids is a field with great challenges for students and researchers who accept them.

Funding Information Open Access funding provided by Projekt DEAL.

Open Access This article is licensed under a Creative Commons Attribution 4.0 International License, which permits use, sharing, adaptation, distribution and reproduction in any medium or format, as long as you give appropriate credit to the original author(s) and the source, provide a link to the Creative Commons licence, and indicate if changes were made. The images or other third party material in this article are included in the article's Creative Commons licence, unless indicated otherwise in a credit line to the material. If material is not included in the article's Creative Commons licence and your intended use is not permitted by statutory regulation or exceeds the permitted use, you will need to obtain permission directly from the copyright holder. To view a copy of this licence, visit http://creativecommons.org/licenses/by/4.0/.

Publisher's note Springer Nature remains neutral with regard to jurisdictional claims in published maps and institutional affiliations.
Werner J.F. Weppner

ww@tf.uni-kiel.de

1 Institut für Materialwissenschaft der Technischen Fakultät der Christian-Albrechts-Universität zu Kiel, Kaiserstr. 2,

24143 Kiel, Germany 